\title{
PESANTREN RAKYAT: \\ Perhelatan Tradisi Kolaboratif Kaum Abangan dengan Kaum Santri Pinggiran di Desa Sumberpucung Kabupaten Malang Jawa Timur
}

\author{
Mufidah. Ch \\ Fakultas Syari'ah UIN Maulana Malik Ibrahim Malang \\ Jalan Gajayana No. 50 Malang, Telp. 08123211786 \\ email: fidah_cholil@yahoo.co.id
}

Abstract

Pesantren is Islamic education base and the oldest Islamic tradition inheritance in Indonesia. As an alternative education institution which is known as opened publicly, that not all people can access this institution because of cultural and psychological obstacles for people who has special needs. While in the fact, people' intention is getting higher towards this Institution. This research aims to describe people's pesantren as the base of collaborative-cultural movement between common people (abangan) and santri in order to change black-world tradition into people-based santri tradition. Through field research or case study using social definition paradigm-qualitative method, observation data collecting technique, interview and documentation, this research reveals that pesantren al Amin is a collaborative cultural realm which is very effective in making common people and santri from poor-marginal area into people-based performance of santri, local wisdom-based with multy strategic-approach of empowerment as sunan Kalijaga's preaching model in spreading Islam in Java island.

Pesantren merupakan basis pendidikan Islam dan pewaris tradisi keislaman tertua di Indonesia. Sebagai lembaga pendidikan alternatif yang dikenal terbuka, namun tidak semua masyarakat bisa mengakses pesantren yang disebabkan hambatan kultural dan psikologis bagi kelompok masyarakat yang berkebutuhan khusus. Sementara animo masyarakat terhadap pesantren sangat tinggi. Penelitian ini bertujuan mendiskripsikan pesantren rakyat sebagai basis gerakan kultural kolaboratif antara kaum abangan dengan kaum santri pinggiran, sehingga dapat 
mengubah tradisi dunia hitam (maksiat) menjadi tradisi santri ala kerakyatan. Melalui penelitian lapangan dengan metode kualitatif berparadigma definisi sosial, menggunakan metode pengumpulan data melalui observasi, wawancara dan dokumentasi, hasil yang diperoleh adalah bahwa Pesantren Rakyat al-Amin merupakan medan budaya kolaboratif yang cukup efektif dalam menyantrikan kaum abangan dan santri pinggiran-miskin ala kerakyatan, berbasis kearifan lokal dengan pendekatan pemberdayaan multi strategic, sebagaimana model dakwah Sunan Kalijaga ketika menyebarkan Islam di Tanah Jawa.

Key words: pesantren, tradition, abangan,santri

\section{Pendahuluan}

Pandangan Dr. Sutomo sebagai outsider masyarakat pesantren, sebagaimana dikutip oleh Dawam Raharjo (1985) bahwa pesantren sebagai warisan budaya Indonesia dapat dilihat dari; Pertama, keberadaan pondok yang menekankan pada sistem dalam pendidikan. Kedua, keakraban hubungan kiai dan santri yang harmonis. Ketiga, mampu mencetak alumni yang bisa memasuki berbagai lapangan pekerjaan dengan bebas dan independen. Keempat, cara hidup kiai yang sederhana. Kelima, pesantren merupakan sistem pendidikan dengan biaya murah (Raharjo, 1985: 34).

Meskipun secara eksplisit pondok pesantren berkonotasi sebagai lembaga pendidikan Islam tradisional, tidaklah berarti seluruh pesantren tertutup dari inovasi. Sejumlah peneliti Barat mengakui bahwa pesantren telah berhasil menjadi penggerak dalam gejolak sosial, ekonomi, politik dan budaya. Perkembangan pesantren semakin menunjukkan geliat modernisasi setelah kemerdekaan RI yang ditandai dengan bertambahnya jumlah putraputri kiai lulusan pesantren yang belajar di lembaga-lembaga non agama dan bertambahnya pengajar pesantren yang bukan berpendidikan pesantren (Jacub, 1984: 63).

Sejak era reformasi, kran demokrasi terbuka lebar, kebebasan berpendapat semakin longgar, turut membangkitkan romantisme politik warga nahdliyyin tahun 1950an di mana pesantren menjadi basis gerakannya. Perubahan sosial politik ini memaksa elit pesantren terjun kembali pada kancah politik praktis. Sikap ini ditempuh dengan sejumlah alasan, antara lain; adanya harapan kebangkitan kembali partai Islam yang pernah berjaya; mempersatukan aspirasi politik kaum santri dari ancaman pecah belah di tengah hingar bingar politik serta merupakan kontribusi elit santri dalam peranannya sebagai agent of change membangun bangsa. Memang posisi kiai dalam konteks ini tidak dapat lepas dari konfigurasi politik, dan perubahan posisi umat Islam di Indonesia yang 
berdampak terhadap sikap dilematis kiai menghadapi pilihan-pilihan strategis dalam relasinya dengan sistem luar pesantren (Dirdjosandjoto, 1999: 22).

Fenomena ini dalam kenyataannya justru menjebak sebagian kalangan pesantren ke dalam penggalangan masa untuk mendukung kepentingan politik tertentu. Pesantren menjadi sasaran empuk para politisi karena, disamping peran kiai sebagai figur karismatik dimanfaatkan sebagai penggerak yang efektif dan efisien, juga besarnya jumlah pemilih riil di kalangan santri dan mudah dikendalikan cukup ampuh dalam meraup perolehan suara pada pemilihan umum legislatif, pemilihan presiden hingga pemilihan kepala daerah. Dalam konteks ini, sebagian besar pesantren telah jauh terlibat dalam aktivitas transaksi politik praktis sedemikian rupa. Hal ini berdampak semakin layunya social capital pesantren seperti keikhlasan, kesederhanaan, kejujuran, keterbukaan, gotong royong dan sebagainya. Satu hal yang sangat memprihatinkan adalah menurunnya kewibawaan dan trust masyarakat.

Dalam situasi yang membingungkan ini, masih menyisakan asa bagi sekelompok outsider pesantren melalui ide kreatif kaum abangan yang berkolaborasi dengan kaum santri pinggiran di Desa Sumberpucung, Kecamatan Sumberpucung, Kabupaten Malang. Mereka mencoba mambangun solidaritas dan semangat gotong royong untuk mewujudkan ruang budaya yang 'unik' yang dinamakan "Pesantren Rakyat". Dengan lahirnya pesantren tanpa dinding ini diharapkan mampu mangakomodir kaum abangan dan kaum santri pinggiran yang ingin belajar agama ala kerakyatan berbasis pemberdayaan agar bisa bangkit, sejahtera dan mandiri. Strategi dan pendekatannyapun sangat persuasif, partisipatif, inklusif, dan natural. Kata "pesantren rakyat" merupakan istilah baru yang belum dikenal sebelumnya, aktivitas dan model memberdayaan para santrinyapun berbasis kearifan lokal, dan dalam waktu relatif singkat mampu mengubah mindset dan perilaku para santri dengan sistem relasi sosial yang berbeda dengan pesantren pada umumnya sehingga cukup menarik untuk diteliti.

\section{Setting Sosial Budaya Masyarakat Desa Sumberpucung}

Masyarakat Sumberpucung merupakan masyarakat beragam dengan gaya hidup kolaborasi masyarakat pedesaan dan semi perkotaan. Secara geografis, masyarakat Sumberpucung terletak di antara Stasiun KA, Pasar Kecamatan, wisata Karangkates, penginapan gelap dan lokalisasi prostitusi. Letak Desa ini memang sangat mendukung berkembangnya tradisi bebas norma agama dan hukum negara. Penduduknya mayoritas beragama Islam abangan dan sebagian 
santri. Tidak ada kiai yang representatif menjadi figur panutan masyarakat, bahkan pernah dirintis sebuah pesantren salaf yang tidak bisa berkembang kemudian mati. Kegagalan lembaga pendidikan Islam ini disebabkan oleh kerasnya tantangan masyarakat terhadap keberadaan pesantren yang kurang dapat beradaptasi dengan kaum abangan mayoritas dengan tradisi kehidupan hitamnya, dan metode dakwah yang kurang tepat sasaran.

Desa Sumberpucung tepatnya Dusun Suko, terdapat lokalisasi prostitusi terbesar di Malang Raya yang berdiri sejak tahun 1955. Berulangkali upaya penutupan tempat maksiat ini selalu gagal, karena kuatnya solidaritas dan dukungan masyarakat sekitar yang menggantungkan mata pencahariannya melalui bisnis ini. Eksistensi lokalisasi yang lebih dari setengah abad ini telah memperkokoh tradisi dunia hitam dan sejenisnya sedemikian kuat sehingga dakwah Islam sulit berkembang.

Kebiasaan melawan norma yang dipahami sebagai bentuk pekerjaan telah mengakar menjadi tradisi trend di kalangan komunitas hitam masyarakat Sumberpucung. Di antaranya adalah perjudian, minuman keras, sabu-sabu, perselingkuhan, prostitusi, hamil di luar nikah dan dunia mistik perdukunan. Kekuatan tradisi ini tidak hanya karena soliditas mereka sangat kuat, juga didukung oleh oknum aparat yang berkedok menjaga keamanan. Mata rantai ini sulit untuk diputus.

Sumberpucung menjadi tempat yang aman bagi pecandu judi dengan berbagai bentuknya, mulai judi dadu (uthuk), remi dan bakaran dengan menggunakan kartu, capsah, cap jiki menggunakan media bola yang digelindingkan, togel hingga judi sabung ayam. Perjudian ini telah terorganisir dengan baik, biasanya dikendalikan oleh 3 atau 4 orang 'bandar kongsi' yang berperan secara bergantian dalam mengendalikan proses perjudian. Di antara bentuk perjudian yang paling eksis di masyarakat Sumberpucung adalah judi 'togel'.

Judi togel memiliki jejaring trans nasional yang dikendalikan oleh bandar besar. Di setiap desa terdapat kurang lebih 20 bandar kecil yang menjadi suplayer atau distributor. Praktik judi togel biasanya secara periodik keluar menunggu hari tertentu dengan kode nomer empat angka/digit, angka 1 disebut 'AS' dan angka terakhir disebut 'buntut'. Karena itu judi togel juga disebut dengan 'buntutan'. Selama menunggu keluarnya angka, pemain disibukkan dengan meramal berdasarkan mimpi, peleng (filling), mistik yang dihitung dengan angkaangka dengan simbol binatang atau benda-benda tertentu yang jumlahnya hingga ribuan. Modus untuk memperoleh informasi mistik tersebut biasanya 
mereka mendatangi dukun, nyepi di tempat-tempat yang dianggap keramat, bahkan mendatangi pertemuan dan pengajian untuk menangkap kosa kata atau angka yang tidak sengaja disebut oleh tokoh masyarakat atau seorang dai dalam forum, kemudian digunakan dasar ramalan. Di antara ramalan berdasarkan modus ini banyak yang berhasil. Dengan demikian, pengajian atau majlis taklim juga menjadi media mencari inspirasi perjudian togel ini.

\section{Sejarah Berdirinya Pesantren Rakyat al Amin}

Pesantren Rakyat al Amin berada di Desa Sumberpucung Kecamatan Sumberpucung Kab. Malang, tepatnya di Barat Daya Pusat Kota Malang atau di bagian Barat dari Kota Kabupaten Malang. Didirikan pada hari Rabu, 25 Juni 2008 oleh seorang aktivis muda pemberdaya masyarakat bernama Abdullah Sam, S.Psi, lulusan UIN Maulana Malik Ibrahim Malang, Fakultas Psikologi kelahiran tahun 1982. Dibesarkan dari representatif keluarga santri termarjinalkan, dengan kehidupan jauh dari kemewahan, di Desa Sumberpucung, di mana dia mencoba merintis sebuah pesantren nyentrik ala kerakyatan.

Pesantren ini dinamakan "Pesantren Rakyat", melalui sebuah renungan dan diskusi kecil Abdullah Sam dengan istrinya Triwiyanti, S.PdI juga sarjana UIN Maulana Malik Ibrahim Malang, Fakultas Tarbiyah. Pesantren ini didirikan atas ide-ide kreatif Cak Dul anak rakyat panggilan akrab ustadz Abdullah yang ingin mengubah kondisi sosial keagamaan lingkungannya melalui pendekatan kultural, natural dan partisipatif. Ia gelisah kemudian mencari metode praktis pengembangan dakwah Islamiyah bagi kaum abangan 'hitam' yang sangat sulit didekati melalui dakwah konvensional yang selama ini dilakukan oleh pada umumnya para dai maupun kiai.

Keprihatinan mendalam yang dia alami berawal ketika Cak Dul melihat sebuah kenyataan hidup bahwa banyaknya anak-anak putus sekolah atau tidak dapat melanjutkan pendidikannya ke jenjang yang lebih tinggi karena orang tua mereka tidak mampu lagi membiayai pendidikan anak-anaknya. Hal ini disebabkan oleh masyarakat tidak memiliki cukup pengetahuan dan keterampilan yang mampu mengubah kondisi mereka dari kemiskinan. Sementara pendidikan formal maupun pondok pesantren terutama yang bercorak khalaf (modern) tidak serta merta bisa menampung mereka dengan gratis. Menurutnya, di lingkungan masyarakat Desa Sumberpucung terdapat beberapa anak yang potensial untuk dididik dan diberdayakan agar kelak dapat memberikan warna baru dan angin segar di lingkungan mereka yang dikenal dengan masyarakat 'hitam' ini. Harapan seorang Cak Dul anak 
rakyat ini diwujudkan dalam bentuk dakwah, pengembangan pendidikan, pemberdayaan umat dan membangun tradisi kerakyatan ala Ahlussunnah Wal Jama'ah. Sasaran dakwahnya dimulai dari lingkungan saudara, kerabat, teman-teman senasib, tetangga, kemudian berkembang semakin hari semakin luas jangkauannya. Setelah melalui proses trail and error, Cak Dul merumuskan pikiran-pikirannya ke dalam Visi Pesantren Rakyat yang semua aktifitasnya ala rakyat yang kemudian dikemas dengan nilai-nilai keislaman, keindonesiaan dan kemanusiaan.

Hingga penelitian ini dilakukan, perjalanan Pesantren Rakyat hampir genap empat tahun. Perkembangan pemberdayaan dan menanamkan tradisi cerdas ala rakyat semakin tampak. Sejumlah program kegiatan inovatif dan kreatif semakin mengalir sebagaimana karakter air. Berbagai kalangan masyarakat silih berganti melakukan kunjungan untuk belajar dari Pesantren Rakyat al Amin tentang bagaimana memberdayakan masyarakat melalui pendekatan integratif kaum abangan dan santri pinggiran.

\section{Sistem Pendidikan Pesantren Rakyat al Amin}

Pesantren didirikan berbasis kerakyatan, pesantren milik rakyat, kurikulum pendidikannya ala rakyat, aktivitas dan kultur belajarnya juga ala rakyat. Pesantren tanpa dinding, tanpa bangunan khusus lazimnya pondok pesantren memiliki santri beragam usia, mulai balita, anak-anak remaja, pemuda, dewasa dan manula. Kalangan muda dan madya lebih mendominasi jumlah santri yang ada. Sistem pembelajarannya sangat fleksibel, materi yang disiapkan menyesuaikan dengan kebutuhan santri, metodenyapun beragam tapi lebih dominan tut wuri handayani dan partisipatif, yang biasa disebut multi level strategic.

Jumlah santri pesantren rakyat hingga penelitian ini dilakukan telah mencapai kurang lebihnya 500 orang dilihat dari kolaborasi santri inti dan santri prima terbagi menjadi dua jenis berikut materi pembelajarannya, yaitu:

Santri Inti: merupakan santri yang berbasis kaum santri terpinggirkan, yang ingin belajar agama dengan model pembelajaran ala pesantren salaf, sehingga materi pembelajarannya diadaptasi dari literatur yang biasa diajarkan di pesantren salaf. Sejumlah alumni pesantren salaf aktif mengajar kitab di pesantren rakyat ini dengan pendekatan pembelajaran ala rakyat seperti contoh-contoh kasus yang diangkat beradaptasi dengan apa yang riil terjadi dalam kehidupan mereka. Materi yang disajikan dalam pembelajaran meliputi, 
pembelajaran baca tulis al Quran dan Pegon (huruf Arab menggunakan bahasa Jawa), dan sejumlah literatur klasik tingkat elementer. Di sela-sela kegiatan pembelajaran kitab juga di adalah Shalawat Nabi, Istighasah, serta khatmi al Quran. Para santri juga dibiasakan gemar membaca buku-buku yang tersedia di perpustakaan Rakyat, diskusi sesama santri. Diselenggarakan pula majlis ta' lim al Amin, pengajian akbar, dan mengadakan wisata ritual ke para kiai dan makam wali.

Santri prima yaitu santri yang berbasis kaum abangan yang hidup normal maupun yang bermasalah dengan potret sosial, seperti bandar togel, koordinator pencopet, bagian keamanan lokalisasi pelacuran, pemabuk dan pengguna narkoba, mantan pelacur, anak jalanan, anak-anak broken home, remaja bermasalah dan sebagainya. Sistem belajarnya tidak mengikuti santri inti sebagaimana santri yang berbasis kaum santri. Kurikulum yang disajikan lebih menekankan pada pembentukan karakter melalui silaturahim, pembiasaan, pengakraban, dan pemberdayaan.

Kegiatan pembentukan karakter dan pemberdayaan bagi santri prima dimaksud melalui: Pertama, pemberdayaan bidang pertanian tanaman organik seperti tanaman bergizi (sayuran), peternakan ayam, jangkrik dan kambing, perikanan berupa ikan lele dan mujair. Kedua, bidang kewirausahaan meliputi usaha asongan, makanan olahan, warung kopi, bakso, budi daya lumut, industri peralatan pertukangan, industri tahu, tempe, susu kedelai dan pedagang sayuran serta mengembangan bisnis wisata sungai dan kolam renang. Ketiga, bidang kesehatan, melakukan pendampingan puluhan masyarakat miskin berobat ke Pukesmas dan RSUD, dan pengobatan pijat refleksi dan akupuntur. Keempat, bidang olah raga dan seni budaya antara lain bola voli, sepak bola, seni kentrung, petruk band, group kleningan, terbang banjari.

Kegiatan yang dilakukan oleh kelompok santri prima ini juga diikuti oleh santri inti. Adapun sejumlah kegiatan pemberdayaan, pelatihan dan pendampingan yang telah dilakukan oleh Pesantren Rakyat al Amin antara lain adalah pelatihan pertanian, kewirausahaan, keterampilan komputer, sablon, jurnalistik, filsafat. Pelatihan keluarga sakinah, kesetaraan gender dan kesehatan reproduksi. Pelatihan komposting, tanaman holtikultur dan vertikultur, budidaya jangkrik dan gerakan menanam pohon dan kebun bergizi. Pendampingan permodalan bekerjasama dengan El Zawa UIN Maliki Malang, dan Bank UMKM Jatim. Pemberian bea siswa bagi santri tidak mampu bekerjasama dengan Badan Amil Zakat (BAZ) Jawa Timur, konseling psikologi, menyediakan khatib shalat jumat. Kegiatan Pesantren Rakyat juga dipublikan 
melalui media. Pendampingan dilakukan dengan sasaran masyarakat kritis dan warga lokalisasi prostitusi. Pesantren Rakyat al-Amin juga menyediakan 1000 buku bacaan dan 3000 buku berbentuk soft ware (CD). Membuka les gratis (study club) bagi siswa dan cangkru'an jagong maton.

\section{Jagong Maton Medan Budaya Santri Abangan}

Mempertimbangkan setting budaya masyarakat Desa Sumberpucung terutama kelompok masyarakat hitam sebagaimana di atas, Ustadz Abdullah mencoba mendekati mereka melalui kader-kader yang dekat dengan kelompok tersebut. Strategi yang dilakukan adalah partisipasi dalam setiap aktivitas group yang disebut cangkru'an di beberapa tempat seperti di dekat stasiun KA Sumberpucung, warung kopi, dan sejumlah gerdu yang menjadi medan budaya dunia hitam. Aktivitas rutin di tiga tempat ini tidak lepas dari minuman keras, narkoba, dan perjudian. Dengan observasi partisipatif ini sejumlah informasi penting tentang aktivitas dan peta kemaksiatan diperoleh secara akurat dan valid. Pendekatan pada basis ini merupakan bentuk nahi munkar secara kultural dengan memasukkan nilai-nilai Islam secara implisit, sehingga mereka merasa nyaman tidak tertekan ataupun dimusuhi. Di lain pihak, ustadz Abdullah juga masuk di sejumlah mushalla, jama'ah tahlil, jama'ah dhiba'iyah, dan majlis ta'lim sebagai bentuk amar ma'ruf dengan pendekatan khas santri.

Dalam perjalan perjuangan yang biasa disebut oleh Cak Dul sebagai "revolusi sosial tanpa dana dan darah" selama lima tahun, secara bertahap ia mencoba mensinergikan kedua kelompok abangan dan santri dalam forumforum silaturahim ala kerakyatan, mendekati anak-anak dan remaja berbasis dua kelompok tersebut. Di samping itu, Cak Dul memanfaatkan tradisi jagongan yang diberi istilah omong-omong klobot yaitu berupa obrolan santai di sore hingga malam hari sambil menunggu waktu tidur, yang telah menjadi tradisi masyarakat pedesaan. Forum in formal ini biasanya mengambil tempat di teras rumah warga sambil merokok, minum kopi dan makanan tradisional pedesaan ala kadarnya. Pada awalnya tema yang diobrolkan di seputar tokohtokoh pewayangan yang dikaitkan dengan kondisi sosial saat itu, masalah pertanian, ternak, dan bercerita tentang keluarga mereka. Tradisi ini masih terus berlangsung hingga sekarang, dengan tema-tema kontemporer, misalnya sepak bola, kenaikan harga BBM, perkembangan politik, harga sembako, BLT (bantuan langsung tunai), termasuk mengkritisi kondisi pemerintah, korupsi, tokoh agama atau kiai dan ulama' yang sibuk dengan urusan politik dan dukung mendukung. Melalui kegiatan omong-omong klobot ini Cak Dul 
memasukkan nilai-nilai Islam dengan bahasa kerakyatan sehingga secara bertahap dapat mengubah mindset dan perilaku mereka.

Sejumlah strategi yang dilakukan ini tampak membuahkan hasil yang ditandai; Pertama, hilangnya gap antara kaum abangan dan santri. Kedua, pendekatan kesejahteraan menyegarkan modal sosial seperti soliditas, gotong royong, kebersamaan, empati satu sama lain sebab mereka merasa memiliki kesamaan sebagai kaum terpinggirkan. Ketiga, gerakan sosial ala kerakyatan merupakan strategi yang tepat bagi mereka karena menggunakan pendekatan persuasive bukan konfrontatif, bottom up dan partisipatif, sehingga tanpa disadari mereka telah berubah tanpa paksaan.

Tiga di antara 30 orang kaum abangan (abang ireng) yang telah berubah dan berhasil menjadi survivor; Pertama, bapak SP mantan bandar judi togel yang berhasil merintis usaha di bidang perdagangan dan pertanian. Kedua, bapak GM dropout kelas IV SD berhasil mengembangkan berbagai jenis usaha termasuk pertanian. Ketiga, bapak JB seorang jago tawur yang tidak pernah kalah, mantan pemabuk, pejudi berhasil merintis usaha dan menjadi pamong Desa. Ketiga survivor ini sekarang telah menjadi pilar penyangga pengembangan Pesantren Rakyat al-Amin. Keikhlasan, kejujuran dan komitmennya luar biasa. Mereka tampil sebagai bagian dari tokoh inspiratif bagi kalangan muda santri abangan.

Semenjak cairnya hubungan kaum abangan dan kaum santri ini, medan budaya cangkru'an dunia hitam berpindah tempat atas inisiatif mereka dengan mengambil istilah "Jagong Maton", yaitu tempat silaturahim santri prima (abangan) dan santri inti kalangan muda dan dewasa. Pesantren Rakyat al-Amin memiliki tiga tempat jagong maton dengan jumlah jama'ahnya empat puluhan orang. Kegiatan dilaksanakan di tiga tempat tersebut secara bergiliran sesuai dengan kesepakatan.

Ketiga tempat jagang maton ini adalah; Pertama, unit gong-gongan bertempat di basecamp Pesantren Rakyat al-Amin dengan jargon berperilaku lokal, berwawasan global. Kedua, unit pembangunan bertempat di rumah bapak Junaidi dengan panggilan rakyatnya "Basman" menggunakan jargon sesuai dengan jabatan pak Basman sebagai aparat desa yaitu sak iyek sak eko proyo bareng-bareng mbangun projo (serentak seiya sekata bersama-sama membangun negara), aluwung ngalah tinimbangane nyalah (mending mengalah dari pada menyalahkan). Ketiga, unit pemberdayaan bertempat di rumah bapak Gugik Mustofa seorang pengusaha yang berangkat dari modal yang sangat minim kemudian berhasil dalam bisnisnya, ia gemar bersedekah untuk fakir miskin. 
Jargon yang dirumuskan unit tiga ini adalah kita yang belajar, kita yang mengajar, dan kita yang memberi gelar.

Setiap kegiatan jagong maton acara dirumuskan bersama dengan susunan acara sebagai berikut: Pertama, para santri berkumpul dengan kostum bebas, kemudian dibuka ala kerakyatan dan abangan yakni tanpa mengucapkan salam ala Islam, sebab masih dalam tahap penyesuaian dengan kebiasaan mereka. Kedua, ngomong-ngomong ngalor-ngidul, berdialog bebas saling menyapa satu sama lain, berkelakar untuk mengkondisikan forum. Ketiga, Gong-gongan atau gamelan mengiringi lagu gending Jawa yang diteruskan tembang (lagu) wajib berjudul Lir-ilir karya Sunan Kalijaga, syi' ir yang biasa dilantunkan Gus Dur yaitu Tombo ati (obat hati), dan Eman-eman gak sembayang (sayang sekali orang yang meninggalkan shalat). Di antara tembang yang menarik adalah syiir yang dilantunkan diawali dengan shalawatan...shalatullah salamulla ala thaha Rasulillah, shalatulloh salamulloh ala yasin habibillah....dan disela dengan lirik yang diadopsi dari nomer dan simbol-simbol judi togel, seperti ....nol siji bandeng nol loro bekecot, nol telu mayit nol limo rampok, nomer sepuluh wong sembayang sewelas kirik nomer rolas jaran...shalatulloh salamullah ala thoha rasulillah....dan seterusnya. Seluruh santri saling memandang, tersipu, menunjukkan ekspresi geli, merasa lucu, mengingat masa lalu mereka ketika masih aktif berjudi togel di dunia hitam yang telah mereka tinggalkan secara berangsur-angsur. Keempat, 'terbangan' atau seni rebana dengan lagu-lagu bernafaskan religious. Kelima, celoteh rakyat berupa ungkapan verbal dan simbol-simbol non verbal merupakan uneg-uneg para santri tentang keluhan, kesulitan, problem kehidupan, dan keinginan maupun harapan yang tidak tersalurkan bisa diungkapkan bebas di forum jagong maton ini. Style bahasa yang digunakan ala kerakyatan seperti bahasa prokem ala aremania, lugas tanpa basa-basi. Kritik sosial dikemas dalam bentuk guyonan thok-ngok (canda spontan), baik ditujukan kepada teman sejawat maupun pimpinannya. Keenam, informasi tentang perkembangan Pesantren Rakyat al-Amin terutama jejaring dengan pihak-pihak terkait dan peluang-peluang yang dapat diakses para santri. Pada kesempatan ini Cak Dul memasukkan nilai-nilai agama dengan tutur kata kerakyatan, membakar semangat juang melawan kemiskinan (miskin aqidah, miskin akhlaq, miskin harta dan miskin ilmu pengetahuan serta keterampilan). Acara diakhiri dengan rencana tindak lanjut berupa kegiatan pemberdayaan jangka pendek biasanya kegiatan yang fisibel seperti membantu fakir miskin, membangun rumah sangat sederhana bagi santri yang belum memiliki tempat tinggal, gerakan menanam pohon atau kebun bergizi, membersihkan lingkungan, pengobatan 
gratis, dan aktivitas sosial kemasyarakat dan keagamaan ala kerakyatan sejenis. Sumber dana diperoleh dari sedekah "cuk" (seikhlasnya). Sehingga tidak ada satupun peserta jagong maton yang tidak berkontribusi dalam pemberdayaan masyarakat sekitarnya.

\section{Pembahasan}

Abdurrahman Wahid menilai pesantren sebagai subkultur dari kultur nasional, karena ia memiliki tradisi sendiri yang unik dan independen, terbebas dari tekanan modernisme yang hegemonik. Dan terus bertahan walaupun mendapatkan cacian sebagai konservatif, terbelakang, jumud dan sebagainya, tetapi karena daya dukungnya kuat, maka tradisi pesantren tetap bertahan sesuai dengan kultur dan iramanya sendiri namun terus berkembang sesuai dengan logika tradisinya sendiri.

Untuk mengenal pesantren sebagai subkultur dengan tradisi yang khas, penelitian Zamakhsyari Dlofier (1995) mengidentifikasi elemen-elemen yang terdapat dalam pesantren meliputi:

Pondok: Pesantren pada dasarnya sebuah asrama pendidikan Islam, di mana santri tinggal bersama untuk belajar di bawah bimbingan kiai. Asrama santri putra biasanya dipisahkan dengan rumah kiai, putra di depan, sedangakan putri di bagian belakang rumah kiai. Pondok atau asrama para santri merupakan cirri khas tradisi pesantren yang membedakan dari sistem pendidikan tradisional di masjid-masjid yang pada umumnya berkembang di negara-negara Islam lainnya.

Masjid: Merupakan elemen penting dari pesantren adalah masjid. Tradisi pembelajaran di masjid merupakan kelanjutan tradisi Islam sejak zaman Rasulullah setelah membangun masjid Quba', masjid yang pertama kali belau dirikan. Masjid merupakan tempat praktik ibadah shalat jama'ah para santri, khuthbah, dan pengajaran kitab klasik. Dalam konteks membangun tradisi pesantren, masjid merupakan sarana melatih kedisiplinan para santri melalui aktivitas keagamaan.

Pengajaran Kitab Klasik: Salah satu elemen pesantren adalah tradisi pembelajaran kitab klasik yang disusun oleh ulama' bermadzhab Syafi'iyah. Tujuan utama pembelajaran ini ialah untuk mempersiapkan calon ulama'. Bagi santri yang tidak lama tinggal di pesantren biasanya bermaksud memperoleh pendalaman perasaan keagamaan, misalnya pada bulan Ramadan. Meskipun dalam perkembangannya pesantren telah mengintegrasikan pengetahuan umum (sain dan teknologi) namun ciri 
khas kajian kitab klasik tetap dipertahankan untuk mencapai tujuan utama pendidikan pesantren.

Santri: Dalam tradisi pesantren, santri terbagi menjadi dua kelompok yaitu; Pertama, santri mukim yakni santri yang berasal dari daerah yang jauh dan menetap dalam kelompok pesantren. Santri yang telah lama bermukim, dipandang senior berperan membantu kiai atau dalam mengelola pesantren dan mengajar santri yunior; Kedua, santri kalong istilah bagi santri yang melaju dari rumah masing-masing (Dirdjosanjoto, 1999: 145), santri yang tidak menetap di pondok pesantren, hadir belajar dan mengaji sesuai dengan jadwal yang ditentukan.

Kiai: Merupakan unsur sentral di pesantren, kiai sebagai pendiri atau penerus peran pengasuh yang sangat menentukan dinamika pesantren. Tumbuh dan berkembangnya pesantren sangat dipengaruhi oleh kompetensi dan kepribadian kiainya. Gelar kiai itu sendiri merupakan pemberian masyarakat kepada seorang ahli agama Islam yang memiliki atau menjadi pimpinan pesantren dan mengajar kitab-kitab Islam klasik kepada para santrinya. Gelar kiai kemudian diberikan pula bagi ahli agama Islam meskipun tidak memiliki pesantren (Dlofier, 1995: 25).

Dalam dinamikanya di masyarakat, pesantren mengalami perkembangan luar biasa. Pembagian pondok pesantren beserta tipologinya sebagai berikut (Jacub,1984: 70-71):

Pesantren Salafi yaitu sistem pesantren yang tetap mempertahankan sistem (materi pengajaran) yang sumbernya dari kitab-kitab klasik Islam atau kitab kuning dengan huruf Arab gundul (tanpa baris apapun). Walaupun kadang-kadang sistem madrasah dipraktikkan sekedar untuk memudahkan sistem sorogan (individual) yang menjadi sendi utama yang diterapkan. Pengetahuan non agama (ilmu pengetahuan) tidak diajarkan.

Pesantren Khalafi yaitu sistem pesantren yang menerapkan sistem madrasah yaitu pengajaran secara klasikal, memasukkan pengetahuan umum dan bahasa non Arabke dalam kurikulum, dan pada akhir-akhir ini menambahnya lagi dengan berbagai keterampilan dan usaha-usaha. Dalam pondok ini biasanya terdapat juga sekolah-sekolah umum. Kitab-kitab klasik hanya sebagai referensi saja terutama dalam perguruan tinggi agama/non agama yang tumbuh dalam pesantren seperti itu.

Pesantren Kilat yaitu pesantren yang berbentuk semacam training dalam waktu relatif singkat dan biasa dilaksanakan pada waktu libur sekolah atau pada bulan Ramadan. Pesantren ini menitik beratkan pada keterampilan 
ibadah dan kepemimpinan. Sedangkan santri terdiri dari pelajar sekolah non pesantren yang dipandang perlu mengikuti kegiatan keagamaan di pesantren atau di sekolah-sekolah.

Pesantren Terintegrasi yaitu pesantren lebih menekankan pada pendidikan vocasional atau kejuruan sebagaimana balai latihan kerja di Departemen Tenaga Kerja dengan program yang terintegrasi. Sedangkan santri mayoritas berasal dari kalangan anak putus sekolah atau para pencari kerja. Alumni pesantren ini diharapkan menguasai ilmu keislaman juga memiliki keterampilan praktis dan kewirausahaan sebagai bekal kehidupan masa depannya.

Di samping pembagian dan tipologi pesantren di atas, perkembangan lebih lanjut bermunculan pula corak dan istilah-istilah baru yang masih dalam korodor pesantren sebagai lembaga pendidikan Islam. Berdirinya ragam pesantren ini menjadi salah satu bagian dari transformasi kultural yang berjalan dalam waktu sangat panjang. Karena hakekat pesantren sebagai titik mula proses transformasi, dengan sendirinya pesantren dipaksa oleh keadaan menjadi alternatif terhadap pola kehidupan yang ada (Rahardjo, 1974: 44). Dengan demikian masih sangat terbuka berdirinya pesantren-pesantren baru dengan ragam coraknya, yang jelas merupakan bukti bahwa pesantren benar-benar tidak dapat dipisahkan dengan masyarakat Indonesia. Di antara keragaman berdirinya pesantren dengan corak dan nama-nama tertentu dewasa ini antara lain:

Pesantren Metal yaitu pesantren yang bercorak kultur salafi, didirikan untuk memberikan pembinaan kepada kalangan muda yang ingin bertaubat dari kebiasaan minuman keras, narkoba, gila, pembinaan anak-anak jalanan dan patologi sosial lainnya. Materi pembelajarannya hampir sama dengan pesantren pada umumnya yaitu menanamkan pendidikan agama, keterampilan (vocation) dan pengasuhan dengan pola-pola khusus. Metode pembelajarannya lebih menekankan pada komunikasi interaksi manusiawi oleh kiai untuk mengentaskan santri menjadi manusia normal dan kembali kepada masyarakatnya. Oleh karena menangani mereka yang berkebutuhan khusus, pesantren metal ini tidak mudah dikembangkan kecuali oleh kiai-kiai yang juga memiliki kompetensi khusus. Misalnya, Pesantren metal dengan nama Pusat Komando Militer Taubat Sunan Kalijaga di Desa Bulusari, Kecamatan Grandungmangu, Kabupaten Cilacap, Jawa Tengah, Pondok Pesantren Muslim Metal, Kecamatan Rejoso, Kabupaten Pasuruan, Jawa Timur.

Pesantren Alam, yaitu pesantren yang dikelola mirip dengan pesantren kilat. Didirikan berawal dari hobi serta kinginan kuat untuk menjelajahi 
bumi Allah secara bebas. Belajar nilai-nilai Islam melalui fenomena alam. Aktivitasnya dikemas dengan istilah camping spiritual. Di pesantren alam diajarkan tantangan, berjuang mengalahkan rintangan. Mengajak berfikir para santri bahwa betapa banyak nikmat Allah yang selalu tercurah kepada manusia. Materi pembelajarannya meliputi keislaman, kepribadian, kepemimpinan dan kecintaan terhadap lingkungan. Dengan menanamkan nilai-nilai Islam melalui alam ini diharapkan dapat menginternalisai nilai-nilai Islam untuk membentuk kekuatan karakter bagi seorang muslim dalam kehidupannya. Misalnya, Pesantren Alam CIRIKO kepanjangan dari Cinta Rimba Kota, Dusun Cilame, Desa Sukamaju, Kecamatan Cigudeg, Kabupaten Bogor, Jawa Barat. Pesantren Alam Ma'rifatussalam, Pesantren Alam Desa Wisata Religius Bubohu, Bango, Batudaa Pantai, Gorontalo, Pesantren Alam Al Azhar, Cigombong, Sukabumi, Jawa Barat, dan sebagainya.

Pesantren Buruh Pabrik, yaitu pesantren yang keberadaannya merupakan pelembagaan dari komunitas buruh pabrik yang ada di sekitar area industri. Pesantren ini merupakan respon dialog nilai-nilai keislaman dengan modernisasiindustrialisasi. Dengan maksud mencari solusi terhadap permasalahan sosial di kalangan buruh pabrik terutama tantangan sekulerisasi yang memerlukan penanganan khusus dalam pendekatan religious. Tumbuh dan berkembangya pesantren ini adalah di sekitar Surabaya, Sidoarjo, Mojokerto dan Gresik. Pesantren Buruh Pabrik mengusung pendidikan seumur hidup, kurikulumnya juga fleksibel dengan prinsip bekerja sambil belajar atau belajar sambil bekerja (Bawani, 2011: 123).

Keempat pesantren ini didirikan berdasarkan kebutuhan dan semangat memecahkan isu-isu sosial keagamaan di masyarakat bernuansa lokal. Sebab hanya dapat diterapkan dalam kondisi tertentu dengan basis pembinaan spisifik dan metode pendekatan lebih lentur, mengalir secara alami. Biasanya elemen yang tersedia dalam pesantren ini tidak seideal yang ada di pondok pesantren salaf maupun khalaf.

Setelah sejumlah sarjana Barat melakukan survey ilmiah baik secara antropologis dan sosiologis di beberapa daerah pedesaan Jawa, maka pembicaraan tentang kelompok komunitas muslim mulai muncul di permukaan dan menjadi obyek penelitian cukup menarik. Salah satu peneliti tentang masyarakat Islam Jawa adalah seorang antropolog asal Amerika bernama Clifford Geertz pada tahun 1960 melakukan studi sosiologis dan antropologis tentang masyarakat dan kebudayaan Jawa yang dibukukan dengan judul The Religion of Java. Tesis utama dalam buku tersebut memunculkan tiga tipologi masyarakat Jawa yang 
bersumber pada filsafat kaum abangan, santri dan priyayi. Effendy (1985) berpandangan bahwa Geertz secara menawan menyajikan style kehidupan varian keagamaan dan tradisi dari setiap kelompok dengan menekankan pada tiga aspek khusus sinkritisme agama Jawa, yaitu animisme, Islam dan Hindu-Budha (Rahardjo, 1985: 37). Berangkat dari tipologi hasil penelitian Geertz ini, kiranya mampu menjembatani bahwa realitas sosial di Jawa hingga sekarang masih dilihat dari tiga kelompok ini, meskipun dalam term tertentu tipologi ini telah banyak digugat oleh peneliti-peneliti sesudahnya.

Jika ditelusuri ke belakang bahwa Islam hadir di pulau Jawa dalam kondisi masyarakat bukan pagan, tetapi telah memeluk agama Hindu-Budha. Kenyataan ini memaksa penyebaran Islam menggunakan pendekatan adaptasi. Penyebaran Islam di Jawa menunjukkan karakteristik adaptative, absorbent, pragmatic and gradualistic a matter of partial compromises, helpway covenants and outright evasions (Geertz, 1968:16). Dengan demikian yang terjadi adalah lebih pada Islam yang "diJawakan" dari pada Jawa yang "diislamkan”.

Dari dua penelitian Geertz di atas, membuktikan bahwa pengelompokan santri dan abangan dalam realitasnya masih ada di masyarakat. Kaum santri Jawa di luar pondok pesantren tidak semuanya dapat mengakses pendidikan pesantren yang bercirikan terbuka dan biaya murah. Ini bisa terjadi sebagai dampak dari modernisasi sistem manajemen pesantren dari tradisional murni menjadi kolaboratif dengan sistem pendidikan modern, di mana pesantren membuka pendidikan formal yang dikelola secara profesional dengan fasilitas yang relatif memadahi. Sebagai konsekuensi dari perubahan ini tidak semua kaum santri dapat memasuki lembaga pendidikan Islam tertua di Indonesia ini disebabkan oleh persyaratan administrasi, biaya hidup dan peralatan belajar yang tidak terjangkau oleh kaum santri dari kalangan status sosial ekonomi lemah.

Di lain pihak, terdapat pula kaum abangan dengan karakteristiknya antara lain adalah memiliki gap komunikasi dengan kaum santri, kendatipun tipologi menurut Geertz ini juga dipertanyakan, namun dalam term ini kaum abangan bahkan akrab dengan dunia hitam dengan perilaku dan budaya melanggar norma agama seperti pasif menjalankan ritual agama, bahkan cenderung konfrontatif terhadap kaum santri, suka mabuk-mabukan, judi togel, prostitusi dan kondisi ekonomi lemah semakin menghalangi penetrasi mereka ke dalam zona santri khususnya pondok pesantren. Sementara pondok pesantren masih menjadi salah satu tujuan orang tua dalam semua kelas sosial termasuk kaum abangan untuk menyekolahkan anak-anak mereka, sebab 
dalam perkembangan akhir-akhir ini, mereka sadar dan memiliki harapan ke depan untuk memperbaiki diri dan generasi penerusnya menjadi lebih baik melalui pendidikan agama.

Uraian di atas menjadi bukti bahwa betapa kuatnya relevansi pesantren dengan masyarakat di Indonesia baik yang bercorak agraris maupun perkotaan. Ketertarikan masyarakat terhadap pesantren sebagaimana disinyalir bahwa, pesantren merupakan lembaga yang mendukung nilai-nilai agama yang di kalangan masyarakat agraris terasa amat dibutuhkan untuk bisa mempertahankan "hawa segar" masyarakat pedusunan, sedang di kalangan masyarakat kota, kebutuhan agama nampaknya lebih banyak dilatarbelakangi oleh pandangan bahwa pergaulan hidup di kota-kota telah mengalami semacam "polusi" yang membahayakan perkembangan pribadi dan pendidikan anak-anak mereka (Rahardjo, 1974:7). Oleh karena itu, mereka tertarik untuk menitipkan anak-anak mereka kepada para kiai agar mendapatkan bimbingan hidup yang baik.

Sebagai lembaga pendidikan alternatif yang seharusnya dapat diakses oleh anak-anak untuk belajar agama dengan lebih baik, namun fenomena di atas menunjukkan suatu yang paradoks. Tidak hanya hambatan ekonomi bagi santri terpinggirkan, tetapi juga hambatan psikologis bagi kaum abangan yang terpinggirkan. Hasil penelitian Mufidah Ch (2010) dengan judul Pembinaan Remaja Miskin Perkotaan di Kelurahan Kasin, Kecamatan Klojen Kota Malang, dengan mengambil sasaran remaja miskin kelompok campuran representatif kaum abangan dan santri pinggiran, menyimpulkan bahwa remaja miskin perkotaan yang distigma sebagai generasi muda tanpa masa depan yang jelas, minim pengetahuan dan keterampilan, dalam kenyataannya juga memiliki hati dan harapan ingin hidup layaknya remaja dengan sentuhan pembinaan yang cukup (Mufidah, 2010: 35). Namun hambatan psikologis seperti konsep diri non assertif, kurang memiliki self confidence (percaya diri) akibat stigmatisasi tersebut merupakan dinding penghalang dalam relasi sosial dengan kelompok lain yang di anggap outsider. Startegi yang perlu dilakukan adalah menggali potensi, minat dan cita-cita mereka untuk menemukan jati diri dan menghadapi masa depan lebih baik. Temuan di lapangan ini merupakan salah satu contoh kasus terjadinya gap kaum abangan dan santri pinggiran dengan kaum santri 'pondokan' (pondok pesantren). Dalam konteks ini 'dinding pondok pesantren' tidak hanya dimaknai sebagai pagar pembatas area pondok dengan dunia luar, tetapi lebih dari itu, sebagai dinding yang membuat sungkan bahkan menakutkan bagi mereka. 
Beda halnya dengan kalangan kaum santri pondokan meskipun dari kelas sosial ekonomi lemah, sangat mudah ketika mengakses pondok pesantren karena mereka menjadi bagian dari keluarga 'dalem' (keluarga kiai) termasuk sistem kekerabatan pesantren atas dasar keturunan, dan atau perkawinan. Adapun bagi kaum abangan pinggiran, mengalami dua kali hambatan; Pertama, tidak adanya modal kekerabatan karena pada umumnya kaum abangan tidak memiliki hubungan keturunan maupun perkawinan dengan santri pondokan; Kedua, hambatan kebekuan sosio-psikologis yang tidak mudah dicairkan kecuali pesantren yang membuka akses bagi mereka dengan sistem pendidikan yang mungkin disebut dengan 'santri berkebutuhan khusus'.

Oleh karena itu peran kiai dalam hal ini sangat penting, sebab visi dan tujuan pesantren diserahkan pada proses improvisasi yang dipilih oleh kiainya atau bersama pembantunya (Madjid, 1992: 6). Ada pula pendapat yang mengatakan kiai menjadi sumber mutlak dari kekuasaan dan kewenangan di pesantren. Menurut hemat penulis, bahwa masalah hambatan kedua inilah yang perlu mendapatkan perhatian, sebagai upaya mengakomodir dan 'menyantrikan' kaum abangan yang ingin mendalami ilmu agama dan praktiknya dalam kehidupan, sebagaimana tujuan awal dilembagakannya dakwah Islam menjadi pondok pesantren era para wali sebagai pioneernya (Dlofier, 1995:56).

Pesantren Rakyat al-Amin merupakan medan budaya nyantrinya kaum abangan. Jika ditelaah kembali tipologi masyarakat Jawa berdasarkan penelitian Geertz (1960) tipologi kaum abangan memiliki garis pemisah dengan kaum santri, namun dalam penelitian ini, kaum abangan yang hidup di dunia hitam penuh kemaksiatan yang penulis istilahkan dengan kaum abang ireng dalam kenyataannya dapat dipertemukan dengan kaum santri meskipun santri dimaksud adalah santri pinggiran. Kekuatan kolaborasi ini terletak pada; Pertama, modal sosial yang dikembangkan melalui pendampingan secara istiqamah berorientasi pada pemberdayaan dan peningkatan serta pemerataan kesejahteraan. Kedua, medan budaya yang bernuansa tradisi lokal, kental dengan simbol-simbol kerakyatan sehingga menimbulkan rasa nyaman khususnya bagi santri abang ireng. Ketiga, pendekatan adaptatif, multi strategic, luwes dan berbasis kearifan local. Keempat; aktor pemimpinnya (Cak Dul) memiliki kredibelitas, integritas, komitmen kuat, istiqamah dalam berjuang serta mampu menjadi tokoh inspiratif bagi santrinya. Kelima, dukungan jejaring stakeholders yang akrab dan memiliki dedikasi yang tinggi dalam mengembangkan lembaga.

Dilihat dari sudut pandang materi pembelajarannya, Pesantren Rakyat 
lebih dekat dengan tipologi pesantren salaf (Jacub, 1984:70-71) yang mengajarkan kitab-kitab klasik ringan bagi santri khususnya santri inti. Dipandang dari aspek pemberdayaannya berorientasi pada vocational, pesantren ini mirip dengan pesantren integratif atau pesantren buruh pabrik yang berorientasi pada belajar seumur hidup, bekerja sambil belajar (Bawani, 2011: 87). Dari sudut pandang basis santrinya dari kaum abangan yang berada di dunia hitam, Pesantren Rakyat hampir sama dengan Pesantren Metal dengan santri binaanya secara sosial tergolong berkebutuhan khusus, sedangkan jika dilihat dari aspek sistem pembelajarannya, metode pendekatan kultural, natural, partisipatif atau multi strategic terutama bagi kaum abang ireng, pesantren ini mengadaptasi strategi para wali khususnya Sunan Kalijaga dalam berdakwah menyebarkan agama Islam di tanah Jawa.

Sunan Kalijaga malakukan dakwah melalui kekuatan budaya jagongan, gamelan, wayangan yang dimodifikasi dan tembang-tembang bermuatan filosofis dan hikmah kehidupan. Misalnya Gamelan Nogowilogo, Guntur Madu, Nyai Sekaty Kiai Sekati, Wayang Kulit Purwo, Tembang Dandang Gula, Sya'ir puji-pujian pesantren (Hadisutrisno, 2010: 179). Kemiripan ini terdapat pada aktivitas jagong maton dengan simbol tradisi Jawa, jargon-jargon yang bermakna dalam membentuk karakter para santri. Proses kegiatannya juga diawali dengan tembang, syi' ir, obrolan kemudian informasi yang disisipi dengan penanaman nilai-nilai Islam ala kerakyatan yang mudah dicerna bagi lakangan awam.

Jika dibandingkan dengan pondok pesantren pada umumnya, Pesantren Rakyat tidak memenuhi elemen-elemen lazimnya pondok pesantren, yaitu asrama (pondok), santri, pembelajaran kitab, kiai, dan masjid. Pesantren Rakyat, pesantrennya rakyat, hanya memenuhi dua unsur yaitu adanya santri, dan pembelajaran kitab yang didukung oleh ustadz ala kerakyatan. Selebihnya merupakan medan budaya yang diislamkan tanpa mengurangi nuansa lokal yang masih mereka pertahankan (Dlofier, 1995: 39). Namun tujuan akhir dakwah bil hal di kalangan masyarakat berkebutuhan khusus ini menjadi sebuah pesantren alternatif yang menginspirasi bagi kaum abangan di daerah lain di Indonesia.

\section{Simpulan}

Pesantren sebagai pusat belajar ilmu keislaman tersebut tidak pernah surut dan lapuk di tengah gelombang dinamika kehidupan bermasyarakat, berbangsa dan bernegara. Bahkan semakin hari semakin menunjukkan geliat luar biasa 
secara kuantitatif maupun kualitatif yang ditandai dengan bermunculannya berbagai model-model pesantren baru yang tidak pernah sepi dari aktivitas ilmiah, dakwah, dan pengembangan masyarakat. Pesantren Rakyat al-Amin merupakan salah satu model pengembangan pesantren alternatif yang cukup prospektif di masa akan datang. Dakwah kultural berbasis pemberdayaan merupakan strategi cukup efektif dalam menyantrikan kaum pinggiran yang ingin belajar agama ala kerakyatan. Internalisasi nilai-nilai Islam adaptatif dengan nafas kearifan lokal dan fisibel menjadi daya tarik bagi santri pinggiran dan kaum abang ireng untuk merevitalisasi diri sebagai manusia relegius, berdaya, sejahtera dan mandiri.

\section{Daftar Pustaka}

Bawani, Imam. 2011, Pesantren Buruh Pabrik, Pemberdayaan Buruh Pabrik Berbasis Pendidikan Pesantren. Yogyakarta: LKiS.

Dirdjosanjoto, Pradjarta. 1999. Memelihara Umat, Kiai Pesantren-Kiai Langgar di Jawa. Yogyakarta: LKiS.

Dlofier, Zamakhsyari. 1995. Tradisi Pesantren, Studi Tentang Pandangan Hidup Kiyai. Jakarta: LP3ES.

Geertz, Clifford. 1960. Relegion of Java.The Free Press of Glencoe.

Geertz, Clifford. 1968. Islam Observed: Religious Development in Marocco and Indonesia. New Haven and London: Yale Univercity Press.

Hadisutrisno, Budiono. 2010. Sejarah Walisongo, Misi Pengislaman di Tanah Jawa. Yogyakarta: GRHA Pustaka.

Jacub, HM. 1984. Pondok Pesantren dan Pembangunan Masyarakat Desa, Bandung: Angkasa.

Lexy J. Moleong. 2006. Metode Penelitian Kualitatif. Bandung: PT Rosda Karya.

Madjid, Nurcholis. 1992. Bilik-Bilik Pesantren, Sebuah Potret Perjalanan. Jakarta:Paramadina

Masud, Abdurrahman. 2004. Intelektual Pesantren, Perhelatan Agama dan Tradisi. Yogyakarta: LKiS.

el Harakah Vol.14 No.1 Tahun 2012 
Mufidah Ch. 2010. Pemberdayaan Remaja Miskin Perkotaan. Penelitian Tidak Dipublikasikan.

Rahardjo, M.Dawam, (Ed.). 1974. Pesantren dan Pembaharuan. Jakarta: LP3ES.

Rahardjo, M.Dawam.1985. Pergulatan Dunia Pesantren, membangun dari Bawah. Jakarta: P3M. 